\title{
LAND SUITABILITY FOR RICE FIELD AND CONSERVATION PLANNING IN HO WATERSHED, TABANAN REGENCY, BALI PROVINCE, INDONESIA
}

\author{
Ni Made TRIGUNASIH ${ }^{1}$ (D), Putu Perdana Kusuma WIGUNA ${ }^{2}$
}

DOI: 10.21163/GT_2020.151.11

\begin{abstract}
:
This study aims to determine the actual extent of land use in the Ho watershed, to determine the suitability of paddy fields and their limiting factors and provide direction for land use in the Ho watershed of Tabanan Regency. Land characteristics as a determinant of land suitability observed include: annual mean temperature, water availability; rooting media; availability of oxygen; nutrient retention, $\mathrm{CEC}, \mathrm{BS}, \mathrm{pH}$, and organic matter; nutrients available; erosion; flood hazard; land preparation. Land suitability assessment is done by matching the quality of the land with the requirements for growing rice. The results showed that the actual land suitability for rice field was classified as not suitable $(\mathrm{N})$ and marginal suitable (S3) with limiting factors: erosion hazard (slope and erosion hazard) and nutrient availability (P-available). Potential land suitability for rice field is classified as very suitable (S1) to marginal suitable (S3) with temperature limiting factors and erosion (slope) hazards. Efforts to improve must be done by adding P fertilizer to areas classified as very low soil Potasium content and maintenance of terraces, especially rice fields with a slope of $>8 \%$ to overcome/prevent erosion and landslides.
\end{abstract}

Key-words: Land suitability, land characteristics, conservation planning

\section{INTRODUCTION}

Properly mapping agricultural land suitability is needed to manage current and future agricultural land use, and for decision makers to develop strategies for sustainable use of land resources (Li et al., 2017). There is a long history of establishing what soils are capable of (FAO, 1976), which is often described as land suitability. The occurrence of land conversion from forest land use, especially in the upstream area, into agricultural land or other uses causes a decrease in the catchment area as an effective area capable of infiltrating rainwater into the ground. The decrease in rainwater infiltration causes water reserves that can be used as water sources in the dry season to be reduced (McBratney \& Field, 2015). In addition, increasing population and high economic pressures in upstream communities have led to the conversion use of land resources without regard to land suitability. The Ho Watershed is located in Tabanan Regency, Bali Province, Indonesia, as one of the largest watershed in Bali Province with total area with an area of 15,367.65 ha. The Ho Watershed consists of various landuses, namely, plantations (6117.63 ha), rice fields $(4,529.15 \mathrm{ha})$, forests $(2,213.31 \mathrm{ha})$, rain-fed rice fields $(1,022.75 \mathrm{ha})$, settlements (894.44 ha), dry land (392.06 ha), bush (98.44 ha), water bodies such (97.80 ha) and pasture (2.05 ha). This watershed is also influenced by climate change phenomena (Suparta \& Yatim, 2019).

\footnotetext{
${ }^{1}$ Udayana University, Faculty of Agriculture, Kampus Bukit Jimbaran, Badung, Bali. 80361, Indonesia.trigunasih@unud.ac.id;

${ }^{2}$ Udayana University, Faculty of Agriculture, Kampus Bukit Jimbaran, Badung, Bali. 80361, Indonesia.wiguna@unud.ac.id.
} 
As one of the largest landuse in Ho watershed, and as the producer of rice, staple food for Indonesia people, the management of rice fields in Ho watershed must meet the principles of land suitability and soil and water conservation to avoid problems in near future. The problems that potentially occur in the Ho watershed are increased erosion which can cause siltation and silting of reservoirs, rivers, canals and other water bodies in the downstream of the watershed. This problem can have implications on decreasing water quality and reducing the potential of water resources, both surface water, springs and ground water. The accumulation of all these problems will lead to the emergence of new environmental problems such as flooding and drought. Erosion that occurs in the upstream area can further reduce the quality of land resources, loss of fertile soil layers, loss of nutrients, damage to soil structure, increased use of energy for production, deterioration of soil productivity, impoverishment of smallholder farmers, reduced alternative land use and others (Arsyad, 2010). Outside the erosion site, especially in the downstream areas of the watershed, there will be siltation and silting of reservoirs, rivers and drainage channels, accumulation of fertile agricultural land, loss of springs and deteriorating water quality, damage to aquatic ecosystems, increased frequency and periods of drought, shortened reservoir life, and increased frequency of flooding (Scholten \& Seitz, 2019).

For this reason, in order to improve the welfare of the farming community in the Ho watershed, landuse in the Ho Watershed must be in accordance with the suitability of the land and its management must meet the principles of soil and water conservation. Therefore it is necessary to conduct research on "Land Suitability for Rice Fields and Conservation Planning in the Ho Watershed, Tabanan Regency".

\section{STUDY AREA AND DATA}

The access to agricultural fields represents the main factor which favors their spatial distribution and their mechanized exploitation (Bilasco et al., 2018). The research is carried out in the Ho Watershed, Tabanan. Administratively the Ho watershed is located in two sub-districts in Tabanan Regency, Bali Provnce, Indonesia, namely Kerambitan sub-district and Penebel sub-district. Astronomically, the Ho Watershed is located at position $115^{\circ} 01$ '26.3 "- $115^{\circ} 09^{\prime} 04.9^{\prime \prime}$ East and $8^{\circ} 16$ '30.2 "- 8 34' 03.7" South. The map of Ho watershed are presented in Fig. 1.

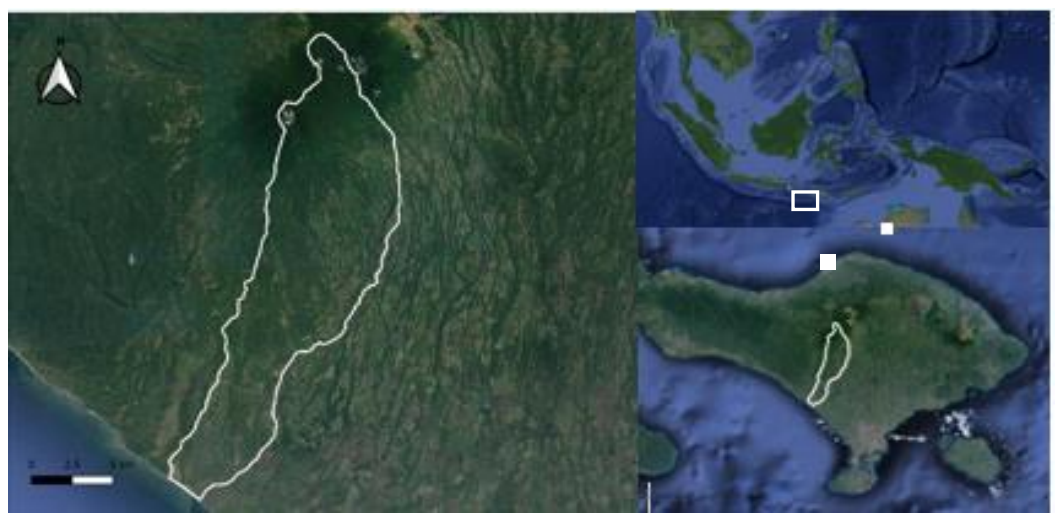

Fig. 1. Research location, Ho watershed. 
The data on land characteristics observed in the field survey are physical characteristics of the soil which include texture, drainage, erosion, and effective root depth, as well as physiographic conditions namely height and slope. Soil analysis to determine soil chemical content includes CEC, BS, C-Organic, N-Total, P- Available, K- Available, salinity, and $\mathrm{pH}$. Data were collected primarily by measurement in the field and secondary by literature studies and maps. This research is conducted through land suitability and soil conservation approaches. This activity consists of a series of activities which include the collection and evaluation of secondary data, surveys, data analysis, and field tests.

\section{METHODOLOGY}

This research was conducted through land suitability and soil conservation approaches. This activity consists of the collection and evaluation of primary data, secondary data, surveys, data analysis, laboratory analysis and field tests. Primary data and secondary data collections are shown in Table 1.

Primary Data and Secondary Data Collection.

Table 1.

\begin{tabular}{|c|l|l|c|l|l|}
\hline No. & \multicolumn{1}{|c|}{$\begin{array}{c}\text { Primary } \\
\text { Data }\end{array}$} & \multicolumn{1}{|c|}{ Source } & No. & \multicolumn{1}{|c|}{$\begin{array}{c}\text { Secondary } \\
\text { Data }\end{array}$} & \multicolumn{1}{c|}{ Source } \\
\hline 1 & $\begin{array}{l}\text { Land Unit } \\
\text { Map }\end{array}$ & $\begin{array}{l}\text { slope map, climate } \\
\text { map, soil type maps } \\
\text { and rice fields, field } \\
\text { surveys }\end{array}$ & 1 & $\begin{array}{l}\text { Bali } \\
\text { Geological } \\
\text { Map, }\end{array}$ & $\begin{array}{l}\text { Geospatial } \\
\text { Information Agency } \\
\text { of Indonesia (BIG) }\end{array}$ \\
\hline 3 & $\begin{array}{l}\text { Land } \\
\text { suitability } \\
\text { for rice field }\end{array}$ & $\begin{array}{l}\text { Overlay of land } \\
\text { suitability factors, field } \\
\text { surveys, laboratory } \\
\text { analysis }\end{array}$ & 2 & $\begin{array}{l}\text { Bali Soil } \\
\text { Type Map, }\end{array}$ & $\begin{array}{l}\text { Geospatial } \\
\text { Information Agency } \\
\text { of Indonesia (BIG) }\end{array}$ \\
\hline $\begin{array}{l}\text { factors for } \\
\text { land } \\
\text { suitability }\end{array}$ & $\begin{array}{l}\text { Overlay of land } \\
\text { suitability factors, field } \\
\text { surveys, laboratory } \\
\text { analysis }\end{array}$ & 3 & $\begin{array}{l}\text { RBI Maps of } \\
\text { Bali }\end{array}$ & $\begin{array}{l}\text { Geospatial } \\
\text { Information Agency } \\
\text { of Indonesia (BIG) }\end{array}$ \\
\hline & & 4 & $\begin{array}{l}\text { Quickbird } \\
\text { satellite } \\
\text { imagery of } \\
\text { Tabanan } \\
\text { Regency }\end{array}$ & $\begin{array}{l}\text { Geospatial } \\
\text { Information Agency } \\
\text { of Indonesia (BIG) }\end{array}$ \\
\hline & & $\begin{array}{l}\text { Rainfall and } \\
\text { Climatology } \\
\text { data }\end{array}$ & $\begin{array}{l}\text { Meteorological and } \\
\text { Geophysical Agency } \\
\text { of Bali }\end{array}$ \\
\hline
\end{tabular}

Definition of criteria affecting the land suitability is one of the most important parts of land evaluation (Arisanti et al., 2019). Before physical data collection activities are carried out in the field, detailed land units are delineated from overlaying slope map, climate map, soil type maps and ricefields map. Land unit map functions to direct sampling in the field. Each land unit then sampled proportionally to its area. Sampling is done by transect in a sloped area and with a grid system in a flat area to the rice fields. Soil samples are taken in layers at a depth of $0-30 \mathrm{~cm}$, whereas to determine the effective depth is continued up to a 
depth of $150 \mathrm{~cm}$ for soils classified as deep or until lytic contact in shallow soils. All data taken from the sampling results are then evaluated in the field, to obtain representative samples. Each soil sample then analyzed in the laboratory to determine the characteristics of the soil. The characteristics of the soil to be analyzed are Soil texture, Organic C, NTotal, P- available, K- available, Cation Exchange Capacity (CEC), Base Saturation (BS), soil $\mathrm{pH}$, and salinity. Land suitability analysis is calculated by comparing the requirements of growing rice field with the characteristics of existing land. The level of land suitability analysis to be used in this study is unit level.

\section{RESULTS AND DISCUSSIONS}

\subsection{Land Unit and Land Characteristics}

Detailed land units are delineated from overlaying slope map, climate map, soil type maps and rice fields map, as its function to create sampling in the field. Each land unit then sampled proportionally to its area. All data taken from the sampling results are evaluated in the field, then analyzed in the laboratory. Based on the overall process using Geographic Information Systems tool, there are six land unit and six samples to analyze. Table 2 shows the land unit of Ho Waterhed. Fig. 2 shows the land unit map of Ho Watershed.

Table 2.

Land Unit of Ho Waterhed.

\begin{tabular}{|c|c|c|c|c|c|c|}
\hline Land Unit & Main material & Physiography & Topography & Soil Type & Slope & Landuse \\
\hline SLH I & $\begin{array}{c}\text { Intermediary } \\
\text { Volkan Ash }\end{array}$ & Beach Ridge & Flat, & $\begin{array}{c}\text { Grayish } \\
\text { Brown } \\
\text { Regosol }\end{array}$ & $0-8 \%$ & Agricultural \\
\hline SLH II & $\begin{array}{c}\text { Ash and } \\
\text { Intermediary } \\
\text { Volkan Tuff }\end{array}$ & Volcanic & $\begin{array}{c}\text { Wavy until } \\
\text { hilly }\end{array}$ & $\begin{array}{c}\text { Yellowish } \\
\text { Brown } \\
\text { Latosol }\end{array}$ & $0-8 \%$ & Agricultural \\
\hline SLH III & $\begin{array}{c}\text { Ash and } \\
\text { Intermediary } \\
\text { Volkan Tuff }\end{array}$ & Volcanic & $\begin{array}{c}\text { Wavy until } \\
\text { hilly }\end{array}$ & $\begin{array}{c}\text { Yellowish } \\
\text { Brown } \\
\text { Latosol }\end{array}$ & $8-15 \%$ & Agricultural \\
\hline SLH IV & $\begin{array}{c}\text { Ash and } \\
\text { Intermediary } \\
\text { Volkan Tuff }\end{array}$ & Volcanic & $\begin{array}{c}\text { Wavy until } \\
\text { hilly }\end{array}$ & $\begin{array}{c}\text { Yellowish } \\
\text { Brown } \\
\text { Latosol }\end{array}$ & $15-25 \%$ & Agricultural \\
\hline SLH V & $\begin{array}{c}\text { Ash and } \\
\text { Intermediary } \\
\text { Volkan Tuff }\end{array}$ & Volcanic & $\begin{array}{c}\text { Wavy until } \\
\text { hilly }\end{array}$ & $\begin{array}{c}\text { Yellowish } \\
\text { Brown } \\
\text { Latosol }\end{array}$ & $25-40 \%$ & Agricultural \\
\hline SLH VI & $\begin{array}{c}\text { Ash and } \\
\text { Intermediary } \\
\text { Volkan Tuff }\end{array}$ & Volcanic & $\begin{array}{c}\text { Wavy until } \\
\text { hilly }\end{array}$ & $\begin{array}{c}\text { Grayish } \\
\text { Brown } \\
\text { Regosol }\end{array}$ & $25-40 \%$ & Agricultural \\
\hline
\end{tabular}

The characteristics/ quality data of ricefields located in Ho Watershed shows that the physical properties of the analyzed soil are soil texture dominated by a rather fine texture (clayey clay and clay), medium texture (clay). Drainage conditions are ranged from rather poor $(\mathrm{ABr})$ to bad $(\mathrm{Br})$. Coarse material, and surface rocks are found in the rice fields located in the upper reaches of the Yeh Ho watershed, which are located in the land units II and III in Mangesta Village and Penatahan Village, Penebel District. Rock outcrops are not found in all irrigated rice fields in the Ho Watershed.The slope of the study site ranges from 
$2 \%$ (flat) to $>45 \%$ (steep). Chemical properties and soil fertility including soil $\mathrm{pH}$ ranges from slightly acidic to neutral, salinity levels range from low to very high, C-organic ranges from very low to high, Soil CEC varies from moderate $(21.79 \mathrm{me} / 100 \mathrm{~g})$ to high $(30.59$ me/100g), base saturation ranges from moderate $(46.15 \%)$ to very high $(107.21 \%)$. N-total is classified as low $(0.18 \%)$ to moderate $(0.35 \%)$, P-available is classified as very low $(1.38$ ppm), to high (10.03 ppm); and K-available is high $(120.58 \mathrm{mg} / 100 \mathrm{~g})$ very high $(334.08$ $\mathrm{mg} / 100 \mathrm{~g})$.

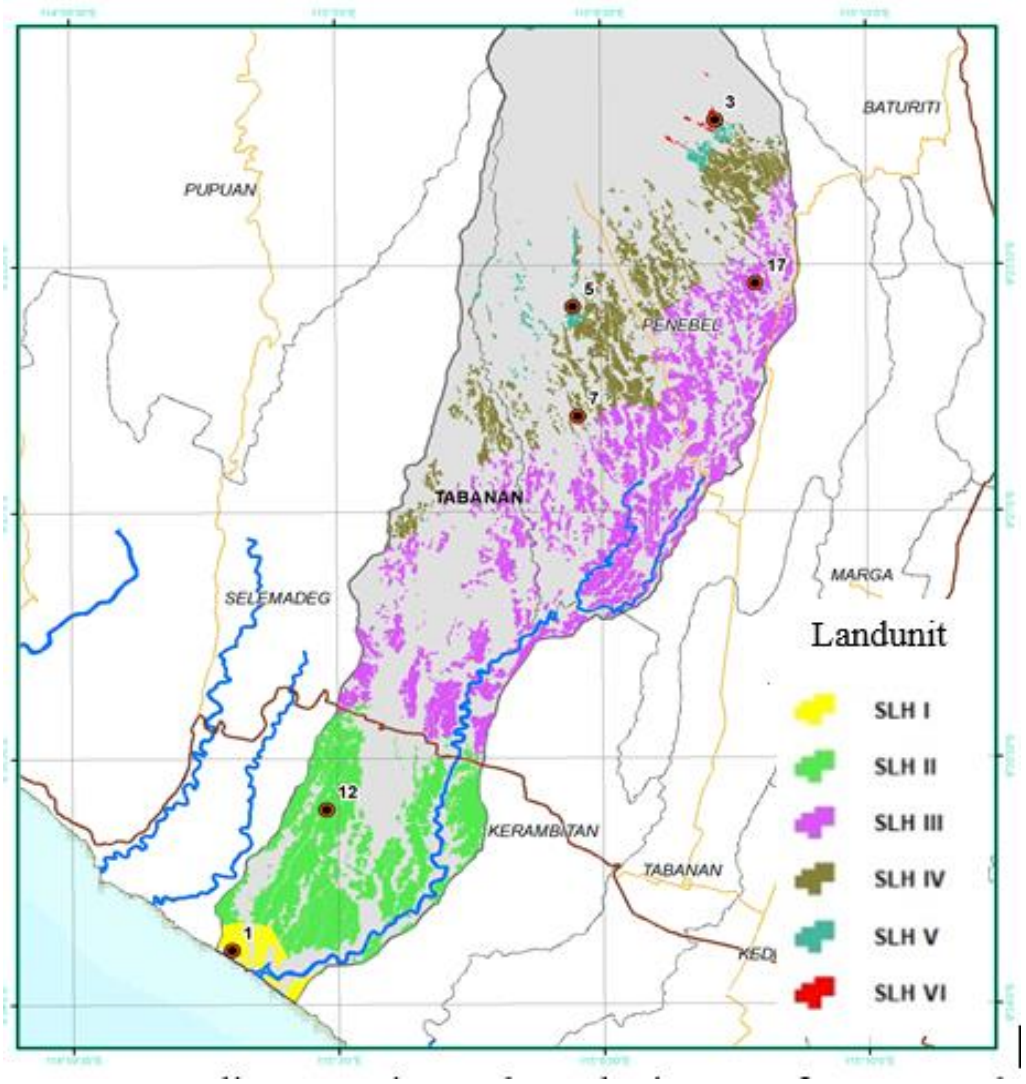

Fig. 2 Land Unit Map of Ho Watershed.

Based on agro-climate data which includes annual mean temperature, rainfall is taken from the Meteorology Climatology and Geophysics Agency of the Central Tabanan Region. Average annual temperatures range from 21.5-28.9 0C, humidity ranges from 58$82 \%$, and annual average rainfall ranges from $1000 \mathrm{~mm}-2000 \mathrm{~mm}$. The Bali Geological Map data, the Yeh Ho watershed has soil types that are dominated by Yellowish Brown Latosol soil types, then followed by the Regosol Brown Gray and Andosol Brown Gray soils. The topography of the area in the Ho watershed is dominated by the form of a undulating to hilly area, then followed by the shape of the hilly to mountainous area in the upstream area of the Yeh Ho watershed, as well as the flat area form in the downstream area of the Ho watershed. 


\subsection{Actual Land Suitability}

Soil and land suitability analysis is very important to identify potential agricultural areas (Rostaminia \& Rahmani, 2019). Actual land suitability is land suitability based on data on the biophysical nature of the land or land resources before the land is given input input needed to overcome obstacles. The biophysical data in the form of soil and climate characteristics are related to the growth requirements of the plants being evaluated. The results of the actual land suitability assessment are assessed from matching between the quality/characteristics of the land with the conditions for growing rice, then the suitability class of ricefields can be determined. Based on the assessment of actual land suitability for rice field, the results are not suitable class (N) in SHL III (Mengesta Village), SHL IV (Penatahan village), SHL V (Wangaya Gede Village) and SLH VI (Jatiluih Village). Marginally suitable class (S3) found in SHL I (Beraban Village) and SHL II (Tangguntiti Village). The suitability of the actual land for ricefields in the Ho Watershed are affected with limiting factors in erosion hazardous land quality, namely slope characteristics and erosion hazard, nutrient availability, especially namely P-available characteristics.

\subsection{Potential Land Suitability}

The actual land suitability for rife fields in the Ho Watershed are classified as not suitable (N) and marginally suitable (S3) with the limiting factors are erosion hazard and land quality ie slope characteristics, erosion hazards, and soil nutrient namely P-available characteristics. By improving the limiting factors so that the actual land suitability can be increased to become the potential land suitability. The potential and actual land suitability in rice fields in the Ho Watershed is presented in Table 3.

Table 3.

Actual and Potential Land Suitability for Ho Watershed.

\begin{tabular}{|c|c|c|c|c|c|c|}
\hline \multirow{3}{*}{$\begin{array}{c}\text { Land } \\
\text { Unit/ } \\
\text { Samples }\end{array}$} & \multirow{3}{*}{$\begin{array}{l}\text { Location } \\
\text { (Village) }\end{array}$} & \multicolumn{4}{|c|}{ Agro ecosystem Land Suitability } & \multirow{3}{*}{$\begin{array}{c}\text { Coordinate } \\
\text { UTM }\end{array}$} \\
\hline & & \multicolumn{4}{|c|}{ Rice Field Suitability } & \\
\hline & & Actual & $\begin{array}{c}\text { Limiting } \\
\text { factor }\end{array}$ & Potential & $\begin{array}{c}\text { Limiting } \\
\text { factor }\end{array}$ & \\
\hline 1 & Beraban & S3eh2, na2 & \begin{tabular}{|c|} 
Hazad Erosion \\
and P-available \\
\end{tabular} & $\mathrm{S} 1$ & - & $\begin{array}{l}282804 ; \\
9053915 \\
\end{array}$ \\
\hline 2 & Tangguntiti & S3na2 & P- available & $\mathrm{S} 1$ & - & $\begin{array}{l}285086 ; \\
9057612\end{array}$ \\
\hline 3 & Mengesta & Neh1 & slope & S3tc, eh1 & $\begin{array}{c}\text { Temperature, } \\
\text { slope }\end{array}$ & $\begin{array}{l}295457 ; \\
9071430\end{array}$ \\
\hline 4 & Penatahan & Neh1 & slope & S3, eh1 & slope & $\begin{array}{l}291162 ; \\
9067927\end{array}$ \\
\hline 5 & $\begin{array}{c}\text { Wangaya } \\
\text { Gede }\end{array}$ & Neh1 & slope & S3tc, eh1 & $\begin{array}{c}\text { Temperature, } \\
\text { slope }\end{array}$ & $\begin{array}{l}291042 ; \\
9070795\end{array}$ \\
\hline 6 & Jatiluwih & Neh1 & Slope & S3tc, eh1 & $\begin{array}{c}\text { Temperature, } \\
\text { slope }\end{array}$ & $\begin{array}{l}294471 \\
9075702\end{array}$ \\
\hline
\end{tabular}

Potential suitability for ricefields in the Ho Watershed is very suitable (S1) to marginal suitable (S3) with limiting factors: temperature (for Mengesta, Wangaya Gede and Jatiluwih Village), and erosion hazards. Suitability of S1 land (very appropriate) is found in 
the downstream of Ho Watershed, locate in SHL I (Desa Beraban) and SHL II in Tangguntiti Village. Improvement efforts that must be made for ricefields in the Ho Watershed is by adding Phosphate element fertilizer at locations classified as very low Phosphate content. Map of actual and potential land suitability are presented in Fig 3.

Agricultural land is a major area with the highest soil erosion rate in Indonesia (Sumiahadi \& Acar, 2019). Soil loss values are highly variable from year to year, as they sdepend on the weather and the land management (Schwilch et al., 2019). One of the most important indicators for land degradation is the progressive salinization of soils (Abidine et al., 2018). Soil conservation structures along with advanced soil loss models would be important toward land management (Bhat et al., 2019). The locations that have very steep slopes, maintenance of terraces are needed to overcome erosion. The direction of land use can be obtained from the suitability of agro ecosystem land with the limiting factors in each one homogeneous land (SHL). Directions for land use that can be recommended for using rice fields are by limiting factor of the level of erosion hazard by overcome by repairing and maintaining the existing bench terrace and planting reinforcement terrace plants and limiting factor of the low availability of P-available nutrients by overcome by adding fertilizers that contain P elements such as SP36.
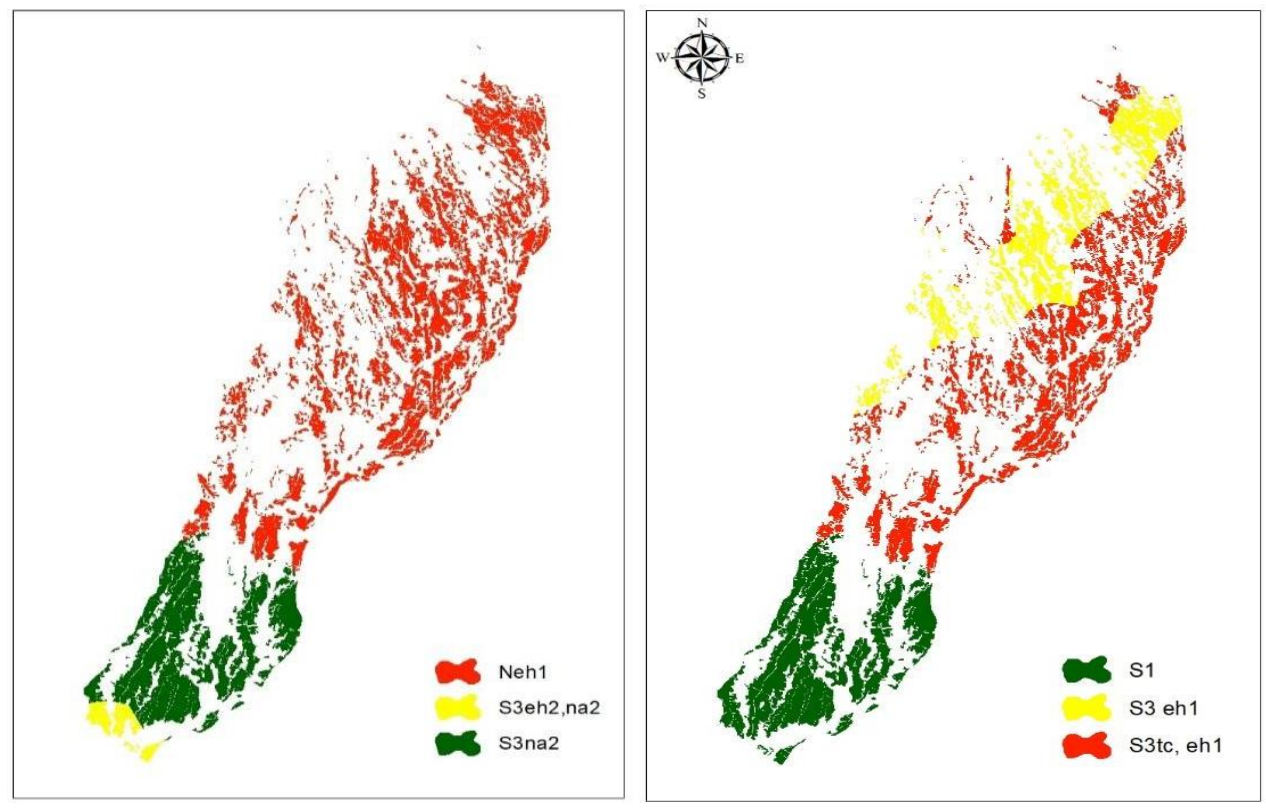

Fig. 3 Actual (left) and Potential Land Suitability (right) for Rice Fields in Ho Watershed.

\section{CONCLUSIONS}

Based on the results and discussion described above, it can be concluded the actual land suitability for ricefields in the Ho Watershed is classified as Not Suitable (N) in SHL III (Mengesta Village), SHL IV (Penatahan village), SHL V (Wangaya Gede Village) and SLH VI (Jatiluih Village) and marginally suitable (S3) found in SHL I (Beraban Village) and SHL II (Tangguntiti Village). The limiting factor in the actual suitability of land is the quality of the erosion hazard land, namely the slope and erosion hazard and the availability 
of nutrients, P-available. Potential suitability for rice field plants in the Ho Watershed is very suitable (S1) to marginal suitable (S3) with limiting factors: temperature (for Mengesta, Wangaya Gede and Jatiluwih), and erosion (slope) hazards. Land suitability of S1 (very suitable) is found in SHL I (Desa Beraban) and SHL II in Tangguntiti Village.

Directions / recommendations that can be given on the use of rice fields are by repairing and maintaining existing bench terraces and planting reinforcing terraces and adding fertilizer containing P elements such as SP36.

\section{ACKNOWLEDGEMENT}

Writers would like to thank the Rector of Universitas Udayana, Dean of Agriculture Faculty of Universitas Udayana, Head of Center for Spatial Data Infrastructure Development (PPIDS) Universitas Udayana, Head of Soil Laboratory of Universitas Udayana, Head of Soil Physics and and Conservation Laboratory of Universitas Udayana fellow staff, researchers and professors at Universitas Udayana for all the supports, comments and suggestions that makes this paper available.

\section{REFERENCES}

Abidine, M.M.O., El Aboudi, A., Kebd, A., Aloueimine , B.B., Dallahi, Y., Soulé, A., Vadel, A. (2018). Modeling the spatial variability of the electrical conductivity of the soil using different spatial interpolation methods: case of the dawling national park in Mauritania. Geographia Technica, 13(2), 1-11.

Arisanty, D., Adyatma, S. \& Normelani, E. (2018). Land suitability evaluation for rice field: farmers' effort to decrease land limitation in Mekarsari, South Kalimantan. 10.2991/icsse-17.2018.10.

Arsyad, S. (2010). Soil and water conservation. Penerbit Institut Pertanian Bogor Press, Bogor.

Bilaşco, T., Roşca, S., Păcurar, I., Moldovan, N., Vescan, I., Fodorean, I., Petrea, D. (2018). Roads accesibility to agricultural crops using GIS technology: methodological approach. Geographia Technica, 13(2), 12-30.

Bhat, S., Dar, M. U., \& Meena, R. M. (2019). Soil erosion and management strategies. Sustainable Management of Soil and Environment, DOI: 10.1007/978-981-13-8832-3_3.

FAO. (1976). A framework for land evaluation. Soils Bulletin, 32. FAO, Rome.

Li, G., Messina, J., Peter, B., \& Snapp, S. (2017). Mapping land suitability for agriculture in Malawi: agricultural land suitability mapping. Land Degradation \& Development. 10.1002/ldr.2723.

McBratney, A. B., Field, D. J. (2015). Securing our soil. Soil Science \& Plant Nutrition, 61.

Rostaminia, M. \& Rahmani, A. (2019). Land suitability evaluation for pistachio and saffron products in Sirvan, Ilam province. 16th Iranian Soil Science Conference, Zanjan University.

Scholten, T. \& Seitz, S. (2019). Soil erosion and land degradation. Soil Systems. 3, 68. 10.3390/soilsystems3040068.

Schwilch, G., Corsin, L., Michael, Z., Prasuhn, V. \& Derungs, N. (2019). Soil erosion policy in Switzerland. Global Symposium on Soil Erosion, FAO, Rome

Sumiahadi, A. \& Acar, R. (2019). Soil Erosion in Indonesia and Its Control. International Symposium for Environmental Science and Engineering Research, Konya, Turkey.

Suparta, W. \& Yatim, A. N. M. (2019) Characterization af heat waves: a case study for Peninsular Malaysia. Geographia Technica, 14(1), 146 - 155. 